ZUR

\title{
GESCHICHTE UND LITERATUR
}

\author{
DES \\ SCHACHSPIELS. \\ FORSCHUNGEN \\ VON \\ T. vON DER LASA.
}

MIT ZAHLREICHEN FIGUREN.

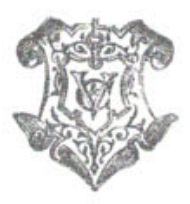

LEIPZIG, VERLAG VON VEIT \& COMP. 1897 . 
Druck von Mtzger \& Wittig in Leipzig. 